\title{
OCCURANCE OF ENTEROBACTERIACEAE IN SKIMMED MILK SOFT CHEESE
}

\author{
AMIRA, O. FARHAT ${ }^{1}$; NAGAH, M. HAFIZ ${ }^{2}$; HALAWA, M.A. ${ }^{2}$;SAAD, M.F. ${ }^{2}$ and \\ AYAH, B. ABDEL-SALAM ${ }^{2}$ \\ ${ }^{1}$ Veterinary Quarantine, Cairo Airport \\ ${ }^{2}$ Department of Food Hygiene and Control, Faculty of Veterinary Medicine, Cairo University, \\ Giza, P.O Box 12211, Egypt
}

Received: 30 May 2017; $\quad$ Accepted: 14 June 2017

\begin{abstract}
Fifty samples of skimmed milk soft cheese were randomly collected from different dairy shops and supermarkets in Cairo and Giza Governorates, Egypt. Collected samples were examined microbiologically for enumeration, isolation and identification of Enterobacteriaceae. The results showed that the mean value of Total Enterobacteriaceae Count was $7.49 \times 10^{7} \pm 0.15 \times 10^{7} \mathrm{cfu} / \mathrm{g}$. Escherichia coli could be found in $64 \%$ of the examined samples with a mean value of $4.56 \times 10^{7} \pm 0.14 \times 10^{7} \mathrm{MPN} / \mathrm{g}$. E.coli serovars O146, O1, O18, O15, O8 and $\mathrm{O} 78$ could be detected in a percentage of $2.90,2.90,4.34,1.45,1.45$ and 1.45 , respectively. Salmonella could not be detected. It could be concluded that skimmed milk soft cheese may harbor serious health risk in the study areas.
\end{abstract}

Key words: Enterobacteriaceae, Skimmed milk soft cheese, Escherichia coli.

\section{INTRODUCTION}

Milk and dairy foods are nutrient-dense foods, supplying energy, proteins and micronutrients (Park et al., 2007). Skimmed milk soft cheese is one of the most popular local types of fresh soft cheeses in Egypt. That may be attributed to its high protein content and low price (Brooks et al., 2012).

Like most perishable foods, the quality of finished dairy products begins with the used raw milk. Milk contaminated by high levels of spoilage bacteria usually becomes unsuitable for further processing in terms of nutritional value, hygienic quality and sensory attributes. The microbiological flora of cheese depends on the quality of raw milk used in manufacture. Many microorganisms may contaminate cheese from various sources during different stages of cheese production, handling, storage and distribution. Raw milk cheese is more likely to harbor harmful bacteria which may constitute an adverse health effect to the consumers (Smith, 1981; Colak et al., 2006; Nanu et al., 2007; Brito et al., 2008 and Callon et al., 2008). Also neglecting the good hygienic and manufacturing practices (GHPs and GMPs) during the processing, handling and product transportation are considered a main source of product contamination with different pathogens and/ or their

Corresponding author: Dr. AYAH, B. ABDEL-SALAM

E-mail address: setelkol2003@yahoo.com

Present address: Department of Food Hygiene and Control, Faculty of Veterinary Medicine, Cairo University, Giza, P.O Box 12211, Egypt toxins (White, 2011).

Enterobacteriaceae have medical and economic importance; their presence in large number indicates faecal contamination, unqualified processing and post processing contamination of food. Enterobacteriaceae spp. has been implicated in many outbreaks (Koneman et al., 1994). This family includes a number of remarkable foodborne pathogens such as Salmonella, pathogenic E. coli and Shigella spp. Other family members are regarded as opportunistic pathogens in clinical settings (Klebsiella spp. and Citrobacter spp.). Erwinia spp. is associated with food spoilage and cause a great economic loss (Baylis et al., 2011). Salmonellae are among the most important and common enteric pathogen that may be transmitted to human through consumption of milk and its products. A dose of as little as 15-20 organisms can cause illness (FDA, 2009). The organism is mainly secreted in the faeces and then picked up on hair or teats of animal. Many strains of Salmonella can cause food-borne infection in humans, and all strains exhibit the same disease symptoms (Jantsch et al., 2011). Last reported 2 outbreaks caused by Salmonella typhimurium were recorded by $\mathrm{CDC}$ in 2013 and it was linked to raw milk and the other for cheese. E. coli, Klebsiella pneumonia, Enterobacter spp. and Citrobacter spp. were involved in gastrointestinal illness as gastroenteritis, food poisoning, cholera-like syndrome, diarrhea, cystitis, pyelonephritis, appendicitis, pyelitis, peritonitis, lobar pneumonia, and septicemia (Graceleah et al., 2010). Escherichia 
coli $\mathrm{O}_{157}: \mathrm{H}_{7}$ is an emerging cause of food borne illness and young dairy cattle are a reservoir for it. Infection with Enterohemorrhagic Escherichia coli (EHEC) strains often associated with food borne outbreaks traced to, milk and dairy products, leads to hemorrhagic colitis (bloody diarrhea) and hemolytic uremic syndrome in humans (Desmarchelier and Fegan, 2011).

\section{MATERIALS AND METHODS}

\section{Collection of samples:}

Fifty samples of skimmed milk soft cheese (Kariesh) were randomly collected under complete sanitary conditions from different dairy shops and supermarkets in Cairo and Giza Governorates, Egypt. Collected samples were transferred to laboratory in an insulated ice-box with minimum of delay to be examined.

\section{Bacteriological examination:}

2.1 Preparation of decimal serial dilutions according to (APHA, 2004).

2.2 Enumeration of Total Enterobacteriaceae Count according to (ISO, 2004).

One $\mathrm{ml}$ of each dilution was transferred into each of appropriately marked duplicate dishes, then approximately $10 \mathrm{ml}$ of the violet red bile glucose medium (Oxoid, CM0485) was poured into each dish. After solidification of the mixture, a covering layer of approximately $15 \mathrm{ml}$ of the violet red bile glucose medium was added to prevent spreading growth and to achieve semi-anaerobic conditions, and then the prepared dishes were incubated at $37^{\circ} \mathrm{C} / 24$ hours. Characteristic colonies were purple or pink to red (with or without precipitation haloes). Such colonies were randomly selected for subculturing for the confirmatory tests (glucose fermentation and oxidase test), then Total Enterobacteriaceae Count was calculated $\mathrm{CFU} / \mathrm{g}$.

2.3 Enumeration and isolation of Escherichia coli (MPN/g) according to (BAM, 2002).

One $\mathrm{ml}$ from each previously prepared decimal dilution was inoculated into a series of 3 fermentation tubes containing Lauryl Sulphate Tryptose (LST) broth (Oxoid, CM0451) supplemented with inverted
Durham's tubes for collection of gas. Inoculated tubes, as well as, the control were incubated at $35^{\circ} \mathrm{C}$ for 48 hours and examined for gas production. From each gassing LST tube (presumptive test), a loopful of each suspension was transferred to Escherichia coli (EC) broth tube (Oxoid, CM0853), EC tubes were incubated for 48 hours at $45.5^{\circ} \mathrm{C}$ and examined for gas production. From the results obtained, MPN/g of $E$. coli was calculated. Loopful from positive tube was streaked on the surface of petri dish containing Levine Eosin Methylene Blue Agar (Oxoid, CM0069) before being incubated at $35^{\circ} \mathrm{C}$ for 48 hours. The plates were examined for suspected colonies of $E$. coli.

\subsection{Isolation of Salmonella according to (ISO, 2002)}

Twenty-five g of skimmed milk soft cheese sample were aseptically added to two hundred and twentyfive $\mathrm{ml}$ buffered peptone water and incubated at $37^{\circ} \mathrm{C}$ for 18 hours. $0.1 \mathrm{ml}$ of the previous culture was transferred to $10 \mathrm{ml}$ of Rapport-Vassiliadis (RVS) medium (Oxoid, 0669) tube. The inoculated RVS broth was incubated at $41.5^{\circ} \mathrm{C}$ for 24 hours, then loopful of the culture obtained in the RVS broth was streaked on the surface of one large size petri dish containing Xylose Lysine Deoxycholate (XLD) agar (Oxoid, 0469). The dishes were inverted and placed in the incubator set at $37^{\circ} \mathrm{C}$ for 24 hours. After incubation, the plates were examined for typical and atypical colonies.

\subsection{Identification of Enterobacteriaceae.}

\subsubsection{Morphological and Biochemical examination} according to (Bergey's manual, 2005).

2.5.2 Biotyping of some Escherichia coli isolates using VITEK 2 compact system according to (Pincus, 2005).

2.5.3 Serological identification of the isolated Escherichia coli according to (BAM, 2011).

Slide agglutination technique, at the Animal Health Research Institute, El- Dokki, Giza, was adopted for serotyping of the same isolates of E. coli, which identified by VITEK 2 compact system, using available coli antisera of BEHRING WEKE AG, MARBURG W., Germany.

\section{RESULTS}

Table 1: Statistical analytical results of Total Enterobacteriaceae Count (CFU/g) and E.coli Count (MPN/g) of the examined skimmed milk soft cheese (Kariesh) samples.

\begin{tabular}{|c|c|c|c|c|c|c|c|}
\hline \multirow{2}{*}{ Parameter } & \multirow{2}{*}{$\begin{array}{l}\text { Total no. } \\
\text { of samples }\end{array}$} & \multicolumn{2}{|c|}{ Positive samples } & \multirow{2}{*}{ Min. } & \multirow{2}{*}{ Max. } & \multirow{2}{*}{ Mean } & \multirow{2}{*}{ \pm S.E.M } \\
\hline & & No. & $\%$ & & & & \\
\hline $\begin{array}{c}\text { Total Enterobacteriaceae } \\
\text { Count }\end{array}$ & 50 & 50 & 100 & $7.0 \times 10$ & $2.2 \times 10^{9}$ & $7.49 \times 10^{7}$ & $0.15 \times 10^{7}$ \\
\hline E. coli Count & 50 & 32 & 64 & $10^{2}$ & $9.46 \times 10^{8}$ & $4.56 \times 10^{7}$ & $0.14 \times 10^{7}$ \\
\hline
\end{tabular}


Table 2: Frequency distribution of Total Enterobacteriaceae and E. coli count in examined samples.

\begin{tabular}{ccccc}
\hline & \multicolumn{2}{c}{ Total Enterobacteriaceae } & \multicolumn{2}{c}{ coli } \\
\hline Intervals & no. of samples & \% & no. of samples & \% \\
\hline$<10^{2}$ & 2 & 4.00 & 18 & 36.00 \\
\hline $10^{2}-<10^{4}$ & 4 & 8.00 & 8 & 16.00 \\
\hline $10^{4}-<10^{6}$ & 14 & 28.00 & 10 & 20.00 \\
\hline $10^{6}-<10^{8}$ & 26 & 52.00 & 14 & 28.00 \\
\hline $10^{8}-\leq 10^{10}$ & 4 & 8.00 & 0 & 0 \\
\hline Total & $\mathbf{5 0}$ & $\mathbf{1 0 0 . 0 0}$ & $\mathbf{5 0}$ & $\mathbf{1 0 0 . 0 0}$
\end{tabular}

Table 3: Incidence of Enterobacteriaceae spp. in examined samples (total no. of isolates=180).

\begin{tabular}{ccc}
\hline Type of isolates & no. & \% \\
\hline Escherichia coli & 69 & 38.33 \\
\hline Klebsiella pneumoniae subsp.ozaenae & 28 & 15.55 \\
\hline Morganella morganii subsp. morganii & 21 & 11.66 \\
\hline Serratia fonticola & 18 & 10.00 \\
\hline Edwardsiella tarda & 10 & 5.56 \\
\hline Citrobacter diversus & 8 & 4.44 \\
\hline Citrobacter freundii & 7 & 3.89 \\
\hline Proteus vulgaris & 4 & 2.22 \\
\hline Enterobacter cloacae & 3 & 1.67 \\
\hline Klebsiella oxytoca & 3 & 1.67 \\
\hline Klebsiella pneumoniae subsp. pneumoniae & 3 & 1.67 \\
\hline Enterobacter aerogenes & 2 & 1.11 \\
\hline Enterobacter intermedius & 2 & 0.56 \\
\hline Serratia liquefaciens & 1 & 0.56 \\
\hline Proteus penneri & 1 & $\mathbf{1 0 0 . 0 0}$ \\
\hline Total & $\mathbf{1 8 0}$ &
\end{tabular}

Table 4: Incidence of E.coli serovars in the examined isolates (no. =69).

\begin{tabular}{ccc}
\hline E.coli serovars & no. of isolates & \% \\
\hline O 146 & 2 & 2.90 \\
\hline O 1 & 2 & 2.90 \\
\hline O 18 & 3 & 4.34 \\
\hline O 15 & 1 & 1.45 \\
\hline O 8 & 1 & 1.45 \\
\hline O 78 & 1 & 1.45 \\
\hline Non typed & 59 & 85.51 \\
\hline Total & $\mathbf{6 9}$ & $\mathbf{1 0 0 . 0 0}$ \\
\hline
\end{tabular}

\section{DISCUSSION}

Manufacture and handling techniques of skimmed milk soft cheese in Egyptian markets are still primitive and unhygienic. Many contaminants find their way to raw milk, from which they gain access to dairy products (Al-Khatib and Al-Mitwalei, 2009). Results presented in (Table 1) revealed that, the Enterobacteriaceae were present in $100 \%$ of the examined skimmed milk soft cheese (Kariesh) samples, which agreed with Hanaa and Jehan (2009) and Sherein et al. (2014). El-Bakery (2004); Ibtisam 
et al. (2006); Dina (2008); Ibrahim et al. (2008); Gihan et al. (2013) and Jehan et al. (2015) recorded lower incidence rate of Enterobacteriaceae than that obtained in this study.

The results registered in (Table 1) revealed that the count of Enterobacteriaceae ranged from $7.0 \times 10$ $\mathrm{CFU} / \mathrm{g}$ to $2.20 \times 10^{9} \mathrm{CFU} / \mathrm{g}$ and a mean value of $7.49 \times 10^{7} \pm 0.15 \times 10^{7} \mathrm{CFU} / \mathrm{g}$. Enterobacteriaceae count is taken as an index for the probable presence of enteric pathogens, which may constitute public health hazards (Eman and El- Kaseh, 2008). These results were lower than that obtained by El-Bakery (2004) and higher than that obtained by Ibtisam et al. (2006); Dina (2008); Hanaa and Jehan (2009); Omar et al. (2011); Abd El-Fattah (2013); Sherien et al. (2014) and Jehan et al. (2015). Nearly similar results were obtained by Ebrahim (1998) and Tirloni et al. (2014). The high rate of contamination with Enterobacteriaceae in skimmed milk soft cheese (Kariesh) may be due to handling, transportation or storage in a place contaminated with these types of bacteria or during processing of cheese which contains low salt (He and Macgregor, 2007). The highest frequency distribution of Enterobacteriaceae count in examined samples lies within the range of $10^{6}-<10^{8} \mathrm{CFU} / \mathrm{g}$ in a percentage of 52 as showed in Table (2). This result was higher than that obtained by (Sherein et al., 2014) who found that the highest frequency distribution of Enterobacteriaceae count in examined skimmed milk soft cheese samples lies within the range of $10^{5}-<10^{6} \mathrm{CFU} / \mathrm{g}$ in a percentage of 41.67

Enterobacteriaceae was used as indicator organisms for assessing hygienic quality of food; because the enteric bacteria that fail to ferment lactose are of more public health importance than those that ferment lactose and their presence could be related to direct or indirect faecal contamination of food (Morales et al., 2003). The data summarized in Table (3) revealed that the identification of Enterobacteriaceae members isolated from the examined samples were Klebsiella pneumoniae subsp.ozaenae, Klebsiella oxytoca and Klebsiella pneumoniae subsp.pneumoniae in percentages of $15.55,1.67$ and 1.67 , respectively. Morganella morganii subsp. morganii, Edwardsiella tarda, Citrobacter diversus and Citrobacter freundii were isolated in percentage of 11.66, 5.56, 4.44 and 3.89, respectively. Also Enterobacter cloacae, Enterobacter aerogenes and Enterobacter intermedius were present in percentages of 1.67, 1.11 and 1.11, respectively. Serratia fonticola, Serratia liquefaciens, Proteus vulgaris and Proteus penneri were present in percentages of 10.00, 0.56, 2.22 and 0.56 , respectively. The highest percentage of Enterobacteriaceae isolates was identified as E. coli in a percentage of $(38.33 \%)$, which is higher than that obtained by Ibtisam et al. (2006) and Omar et al. (2011) and lower than that obtained by Baraheem et al. (2007) and Uraz et al. (2008).
Klebsiella pneumoniae is a world wide spread bacteria that could be responsible for arthritis, meningitis, appendicitis, cystitis, pneumonia and septicemia in newborns (Bernabe et al., 1998). Results of Klebsiella spp. isolated from samples were higher than that obtained by Falegan and Akere (2014) and lower than that obtained by Ogbolu et al. (2014) and Uraz et al. (2008). Klebsiella pneumoniae subsp. ozaenae isolated from samples was lower than that obtained by Aya (2014) and higher than that obtained by Elbagory et al. (2016). Klebsiella oxytoca isolated from cheese samples was lower than that obtained by Tornadijo et al. (2001) and Abd El-Fattah (2013). $K$. pneumonia and $K$. oxytoca cause community-acquired meningitis and brain abscesses (Janda and Abbott, 2006). Citrobacter freundii isolated from cheese samples was lower than obtained by (Ibtisam et al., 2006 and Abd El-Fattah, 2013). Results of Serratia spp. isolated from cheese samples were lower than that obtained by (Uraz et al., 2008); also results of Proteus spp. isolated were lower than that obtained by (El Sayed et al., 2011).

Morganella morganii is a Gram-negative rod which could be found naturally in the environment and as normal flora in the intestinal tracts (Miller, 2015). Morganella morganii isolated from cheese samples was lower than that obtained by (Uraz et al., 2008). Salmonella failed to be isolated from all examined samples neither by using violet red bile glucose agar nor by selective (XLD medium). The absence of Salmonella in the examined samples makes these samples complied with the Egyptian standards in this point. Escherichia coli are representing a portion of the intestinal tract normal microflora of animals and human. Also it is used as indicator microorganism to detect and measure fecal contamination in the evaluation of food safety (Borgatta et al., 2012). E. coli presence in food not only indicates contamination, poor hygiene and sanitary practice but also it could be hazardous for consumers (Hahn, 1996). In Table (1), it was obvious that E. coli incidence rate in the examined samples was $64 \%$ either by selective EMB or Violet Red Bile Glucose agar medium, which was higher than that obtained by Walaa (2008); Hanaa and Jehan (2009); Omar et al. (2011); Eman (2012); Abd El-Fattah (2013); El nahas et al. (2015) and Elbagory et al. (2016), while Najand and Ghanbarpour (2006); Omar et al. (2007); Campos et al. (2009) and Enas (2015) reported higher incidence. $E$. coli were found in the examined samples with a minimum count of $10^{2} \mathrm{MPN} / \mathrm{g}$, maximum count of $9.46 \times 10^{8} \mathrm{MPN} / \mathrm{g}$ and a mean value $4.56 \times 10^{7} \pm 0.14 \times 10^{7} \mathrm{MPN} / \mathrm{g}$ Table (1). The count of $E$. coli in this study was lower than that obtained by Alper and Nesrin (2013). Bahout and moustafa (2006); El nahas et al. (2015) and Enas (2015) could enumerate E. coli in lower count. The highest frequency distribution of $E$. coli count in the examined samples was $<10^{2} \mathrm{MPN} / \mathrm{g}$ in percentage of 36 as showed in Table (2). E. coli is one of the most 
important food-borne pathogens and has been involved in many outbreaks associated with severe symptoms and highly fatality rate (Doyle and Beuchat, 2007). The serological typing of the E. coli isolated from skimmed milk soft cheese samples were identified as O146, O1, O18, O15, O8 and 078 in percentage of $2.90,2.90,4.34,1.45,1.45$ and 1.45 , respectively, and non-typed isolates could be detected from the samples in a percentage of 85.51 as shown in (Table 4). Shiga Toxigenic Escherichia coli (STEC) are known as important pathogens and have been associated with diarrhea and Hemolytic Uremic Syndrome (Paton and Paton, 1998). E. coli O146 strains belong to this group and have been implicated in human diseases (Beutin et al., 2004). Also E. coli O78 belongs to STEC group and associated with enteritis, newborn meningitis and sepsis (Gophna et al., 2001). The Enterotoxigenic E. coli such as O8, O27 and O78, secretes toxins, which lead to the production of a watery diarrhea and severe dehydration in children (Cohen and Gianella, 1995 and Fratamico et al., 2002).

\section{CONCLUSION}

The results in this study revealed that the Egyptian skimmed milk soft cheese samples were heavily contaminated with Enterobacteriacae spp. and the isolated strains constitute public health hazard to consumer. Bad hygienic quality of raw milk used in cheese manufacturing could be considered as the potential source of cheese contamination. The objectionable heavy contamination of cheese samples with different types of Enterobacteriacae may result into serious changes in the product rendering it of inferior quality. Moreover, being an important vehicle for the transmission of milk-borne pathogens to consumers. Routine assessment of skimmed milk soft cheese quality produced by small-scale livestock keepers has to be mandatory in order to safeguard the public from milk-borne zoonotic infections. Strictly hygienic measures should be applied during the whole chain of cheese production starting from milking of milk, all manufacturing steps, storage and distribution of cheese. The behavior of consuming raw milk and products made from raw milk should be discouraged. Good Manufacturing Practices (GMP), Good Hygienic Practices (GMP) and strict personal hygiene are the way to ensure safety and high quality of dairy products. It is concluded that a gradual move to total Enterobacteriacae (measure of food quality and spoilage) to improve assessment of food safety and quality rather than limiting examination for coliforms and fecal coliforms.

\section{REFERENCES}

Abd El-Fattah, S.A.S. (2013): Microbial profile of some dairy products. Ph.D. Thesis, Fac. Vet. Med., Alexandria Univ., Egypt.
Al-Khatib, I.A. and Al-Mitwalei, S.M. (2009): Microbiological quality and sample collection policy for dairy products in Ramalla and AlBireh district, Palestine East Mediterranean Health J., 15: 709-716.

Alper, S. and Nesrin, C. (2013): Bacterial contamination in fresh white cheeses sold in bazaars Canakkale, Turkey. International Food Research J. 20(3): 1469-1472.

APHA "American Public Health Association" (2004): Standard methods for the examination of dairy products, 17th Ed. American public health association.

Aya, A.M.A. (2014): Studies on some food poisoning organisms in milk and some locally produced soft cheese Fac. Vet. Med., Sadat city Univ.

Bahout, A.A. and moustafa, A.H. (2006): Occurrence of some microorganisms in relation to public health importance in kareish cheese. Assiut Vet. Med. J; 52: 85-93.

BAM, Bacteriological Analytical Manual (2002): Enumeration of Escherichia coli and the Coliform Bacteria. Chapter 4. U.S. Food and Drug Administration Center for Food Safety and Applied Nutrition.

BAM, Bacteriological Analytical Manual (2011): Diarrheagenic Escherichia coli. Chapter 4A Bacteriological Analytical Manual. U.S. Food \& Drug Administration Center for Food Safety and Applied Nutrition.

Baraheem, O.H.; Hoda, A.E.; Wafaa, M.B. and Naglaa, F.G. (2007): Bacteriological quality of some dairy products (kariesh cheese and ice cream) in Alexandria. J Egypt Public Health Assoc 82 (5 \& 6).

Baylis, C.; Uyttendaele, M.; Joosten, H. and Davies, A. (2011): The Enterobacteriaceae and their significance to the food industry, the international life science institute (ILSI) Europe Emerging Microbiological Issues Task Force.

Bergey's manual (2005): Bergey's manual of Systematic Bacteriology 2nd Ed Volume Two The Proteobacteria Part B The Gammaproteobacteria.

Bernabe, A.; Contreras, A.; Gomez, M.A.; Senchez, A.; Corrales, J.C. and Gomez, S. (1998): Polyarthritis in kids associated with Klebsiella pneumonia. Veterinary Record, 142 (3): 64-66.

Beutin, L.; Krause, G.; Zimmermann, S.; Kaulfuss, S. and Gleier, K. (2004): Characterization of Shiga toxin-producing Escherichia coli strains isolated from human patients in Germany over a 3-year period. J Clin Microbiol; 42: 1099-108.

Borgattaa, B.; Kmet-Lunacekb, N. and Relloc, J. (2012): E. coli O104:H4 outbreak and hemolytic - uremic syndrome. Med. Intensiva., 10:1016. 
Brito, J.R.F.; Santos, E.M.P.; Arcuri, E.F.; Lange, C.C.; Brito, M.A.V.P. and Souza, G.N. (2008): Retail survey of Brazilian milk and Minas frescal cheese and a contaminated dairy plant to establish prevalence, relatedness, and sources of Listeria monocytogenes isolates. Applied and Environmental Microbiology, 74: 49544961.

Brooks, J.C.; Martinez, B.; Stratton, J.; Bianchini, A.; Krokstromb, R. and Hutkins, R. (2012): Survey of raw milk cheeses for microbiological quality and prevalence of foodborne pathogens Food Microbiology 31: $154-158$

Callon, C.; Gilbert, F.B.; Cremoux, R.D. and Montel, M.C. (2008): Application of variable number of tandem repeat analysis to determine the origin of $S$. aureus contamination from milk to cheese in goat cheese farms. Food Control, 19: $143-150$.

Campos, M.R.H.; André, M.C.D.P.B.; Borges, L.J.; Kipnis, A.; Pimenta, F.C. and Serafini, A.B. (2009): Genetic heterogeneity of Escherichia coli strains isolated from raw milk, Minas Frescal cheese, and food handlers .Arq. Bras. Med. Vet. Zootec., 61(5): 1203-1209.

Cohen, M.B. and Gianella, R.A. (1995): Enterotoxigenic Escherichia coli. In: M. J. Blaser, P. D. Smith, J. I. Ravdin et al. (eds), Infections of the Gastrointestinal Tract, Raven Press, New York, pp. 691-707.

Çolak, H.; Hampikyan, H.; Bingöl, E.B. and Ulusoy, B. (2006): Prevalence of Listeria monocytogenes and Salmonella spp. in Tulum cheese. Food Control 18: 576-579.

Desmarchelier, P. and Fegan, N. (2011): Pathogens in Milk Escherichia coli. Encyclopedia of Dairy Sciences (Second Edition) 2011, Pages 60-66.

Dina, N.A. Moustafa (2008): Microbiological status of kareish cheese produced in dairy plants and farmers houses. (M.V.Sc.)Thesis, Fac. Vet. Med., Assiut univ.

Doyle, M.P. and Beuchat, L.R. (2007): Food Microbiology, 3rd edition ASM Press. Washington DC, 187-219.

Ebrahim, N.H.A. (1998): Occurrence of enterobacteriaceae in milk and kareish cheese. (M.V.Sc.). Thesis, Fac. Vet. Med. Zagazig Univ.

El nahas, A.W.; Mohamed, H.A.; El barbary, H.A. and Mohamed, H.S. (2015): Incidence of E. coli in raw milk and its products. Benha Veterinary Medical J. 29(1): 112-117.

El Sayed, M.A.; Hosny, I.M.; El Kholy, W.I.; El Dairouty, R.K. and Sahar, H.S.M. (2011): Microbiological evaluation of Egyptian white soft cheeses style. Journal of American Science 7(5): 517-526.
Elbagory, A.M.; Hammad, A.M. and Alzahraa, M.A.Sh. (2016): Prevalence of coliforms, antibiotic resistant coliforms and E. Coli serotypes in raw milk and some varieties of raw milk cheese in Egypt. Nutr Food Technol 2(1).

El-Bakery, Z.T.A. (2004): Enterobacteriaceae in milk and some dairy products focusing on salmonellae and e. coli 0157:h7. (Ph.D.). Thesis, Fac. Vet. Med. Banha univ.

Eman, H.A. (2012): Assessment of hygienic status of raw milk and some dairy products, (M.V.SC.) thesis, Fac. Vet. Med. Damnhour Univ., Egypt.

Eman, M.E. and El- Kaseh, R.M. (2008): Microbiological monitoring of raw milk and yoghurt samples collected from El-Beida city, Arab J. Biotech., 12: 57-64.

Enas, A.S.M. (2015): Studies on entric pathogens in milk and some dairy products with especial reference to salmonella. (M.V.Sc.) Thesis, Fac. Vet. Med., Beni-Suef Univ.

Falegan, C.R. and Akere, G.A. (2014): Isolation of Salmonella spp In 'Wara' (Local Cheese) From Three Different Locations In Ado-Ekiti, Ekiti State, Nigeria. The Experiment, 23 (4): 1628-1634.

FDA (Food and Drug Administration) (2009): Dairy Products - Microbial Contaminants and Alkaline Phosphatase Activity. FDA/ORA Compliance Policy Guide , sec. 527/300 (Issued: 2009). Department of Health and Human Services, Public Health Service, Washington, DC.

Fratamico, P.M.; Smith, J.L. and Buchanan, R.L. (2002): Escherichia coli. In: Foodborne Diseases (Cliver, D.O. and Riemann, H.P.Eds.). $2^{\text {nd }}$ Ed.Academic Press, Elsevier Science LTD, pp. 79-100.

Gihan, M.O.M.; Hanan, A.E. and Riad, E.M. (2013): Prevalence of enteric bacteria producing toxins in ice-cream and kareish cheese in Port-Said city markets. Assiut Vet. Med. J. 59 (136).

Gophna, U.; Oelschlaeger, T.A.; Hacker, J. and Ron, E.Z. (2001): Yersinia HPI in septicemic Escherichia coli strains isolated from diverse hosts. FEMS Microbiol. Lett. 196: 57-60.

Graceleah, O.; Orallo, A. and Esperanza, C. (2010): Microbial analysis of ice cream produced by big scale and small scale manufacturers in Metro Manilla. Int. J. Microbiol. 28 (3) 99103.

Hahn, G. (1996): Pathogenic bacteria in raw milk situation and significance. proceeding of bacteriological quality of raw milk. International Dairy Federation, Brussels (Belgium) 67-83.

Hanaa, M.F. and Jehan, I. (2009): Prevalence and significance of Staphylococcus and Enterobacteriaceae species in selected dairy 
products and handlers. International $\mathrm{J}$. of Dairy Science.

He, F.J. and Macgregor, G.A. (2007): Dietary salt, high blood pressure and other harmful effects on health. In: Kilcast, D. and Angus, F. (eds) Reducing salt in foods: Practical strategies. Cambridge, UK 18-54.

Ibrahim, H.A.; Salah, F.A. and Monah, H.T. (2008): Presence and activity of psychrotrophic bacteria in raw cow s milk and some dairy products. $9^{\text {th }}$ Vet. Med. Zag. Conference: 2022 Port-Said.

Ibtisam, E.M.E.; Sanaa, B.O.E. and Sanaa, O.Y. (2006): Occurance of Enterobacteriaceae in Sudanese white cheese in restaurants of Khartoum State (Sudan). Research J. of Microbiology 1(1):76-82.

ISO, International Standard Organization (2002): ISO standard6579:2002(E). Microbiology of food and animal feeding stuffs- Horizontal methods for detection of Salmonella spp.

ISO, International Standard Organization (2004): ISO standard 21528-2:2004(E). Microbiology of food and animal feeding stuffs_Horizontal methods for detection and enumeration of Enterobacteriaceae_Part 2: Colony-count method.

Janda, J.M. and Abbott, S.L. (2006): The Genera Klebsiella and Raoultella. The Enterobacteria (2nd ed., pp. 115-129). Washington, USA: ASM Press.

Jantsch, J.; Chikkaballi, D. and Hensel, M. (2011):

"Cellular aspects of immunity to intracellular

Salmonella enterica". Immunological Reviews 240 (1): 185-195.

Jehan, I.I.; Salama, E.S.A. and Alaa, A.H. (2015): Microbial quality of some dairy products in Ismailia city. Conference of Food Safety, Suez Canal University, Faculty of Veterinary Medicine. I: 14-21.

Koneman, W.E.; Allen, S.D.; Janda, W.M.; Schreckenberger, P.C. and Winn, W. (1994): Introduction to Diagnostic microbiology Lippincott Publishers, Philadelphia, USA.

Miller, J.R. (2015): Morganella infections. http://emedicine.medscape.com/article/222443overview.

Morales, P.; Fernandez, G.E. and Nunez, M. (2003): Caseinolysis in cheese by Enterobacteriaceae strains of dairy origin. Lett Appl. Microbiol., 37: 410-414.

Najand, L.M. and Ghanbarpour, R. (2006): A study on enteropathogenic Escherichia coli isolated from domestic Iranian soft cheese. Vet. arhiv 76(6): 531-536.

Nanu, E.; Latha, C.; Sunil, B.; Prejit, T.M. and Venon, K.V. (2007): Quality assurance and public health safety of raw milk at the production point. American Journal of Food Technology 2, 145-152.
Ogbolu, D.O.; Terry Alli, A.O.; Oluremi, A.S. and Olanrewaju, A.A. (2014): Microbial contamination of locally produced cheese and determination of their antimicrobial potential in Nigeria. African Journal of Clinical and Experimental Microbiology. ISBN 1595689X, 15(2).

Omar, H.B.; Hoda, A.E.; Wafaa, M.B. and Naglaa, F.G. (2007): Bacteriological quality of some dairy products (kareish cheese and icecream) in Alexandria. J. Egypt Public Health Assoc., 82(5 \& 6).

Omar, Sh.S.; Dababneh, B.F.; Qatatsheh, A.; AbuRomman, S.; Hawari, A.D. and Aladaileh, S. (2011): The incidence of Listeria species and other indicator bacteria in some traditional foods sold in Karak city, Jordan. J. of Food, Agriculture and Environment, 9 (2): 79 - 81.

Park, Y.W.; Juárez, M.; Ramos, M. and Haenlein, G.F.W. (2007): Physico-chemical characteristics of goat and sheep milk. Small Ruminant Res., 68(1-2): 88-113.

Paton, A.W. and Paton, J.C. (1998): Detection and characterization of Shiga toxigenic Escherichia coli by using multiplex PCR assays for stx1, stx2, eaeA, enterohaemorrhagic E. coli hlyA, rfbO111, and rfbO157. J Clin Microbiol., 1998 Feb; 36(2): 598-602.

Pincus, D.H. (2005): Microbial identification using the Biomerieux, VITEK 2 system. In Miller, M.J. (Edi), Encyclopedia of rapid microbiological methods, Volume $1,1^{\text {st }}$ Edition.US.

Sherien, E.N.; Mahrous, H. and El-Bagory, A.M. (2014): Enterobacteriaceae in some locally produced cheese. Minufiya Vet. J. 8 (1): 115123.

Smith, P.W. (1981): Milk Pasteurization Fact Sheet Number 57, U.S. Department of Agriculture Research service, Washington, D.C 4. Hausler, W.J.JR. (1972). Standard M ethods for the Examination Diary Products .

Tirloni, E.; Stella, S. and Bernardi, C. (2014): Concerns about the microbiological quality of traditional raw milk cheeses: a worldwide issue. - Int. J. of Health, Animal science and Food safety 2: $24-31$.

Tornadijo, M.E.; García, M.C.; Fresno, J.M. and Carballo, J. (2001): Study of Enterobacteriaceae during the manufacture and ripening of San Simón cheese. Food microbiology, 18(5): 499-509.

Uraz, G.; Coskun, S. and Ozer, B. (2008): Microflora and pathogen bacteria (Salmonella, Klebsiella, Yersinia, Pseudomonas, Aeromonas, Escherichia coli, Staphylococcus aureus) In Urfa Cheese (A Traditional WhiteBrined Turkish Cheese). Pakistan Journal of Nutrition 7 (5): 630-635. 
Walaa, S.A.H. (2008): Microbiological evaluation of some white soft cheeses locally manufactured and sold in Assiut city. (M.V.Sc.) Thesis, Fac. Vet. Med., Assiut Univ.
White, C.H. (2011): Effect of Storage and Transport on Milk Quality. Mississippi State University, Starkville, MS, USA, Randolph Associates, Inc., Birmingham, AL, USA, 2011 Elsevier.

\section{مدى تواجد الميكروبات المعوية فى الجبن الطرى منزوع الاسم}

\section{أمبره فرحات ، نجاح مصطفى حافظ ، محدى أحدد حلاوه ، مينا فؤاد سعد ، ايه عبد السلام}

Email: setelkol2003@yahoo.com Assiut University web-site: www.aun.edu.eg

يعتبر الجبن الطرى منزوع الدسم (الجبن القريش) من أشهر أنواع الجبن الطرى فى مصر لقيمته الغذائية العالية وسعره المنخفض.

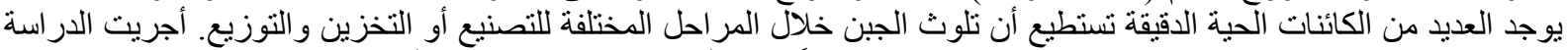

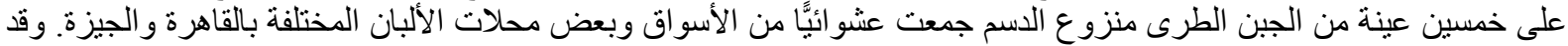

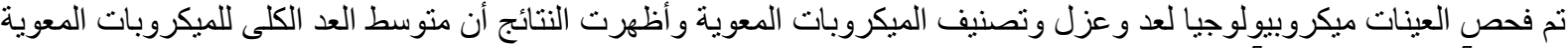
كالتالى

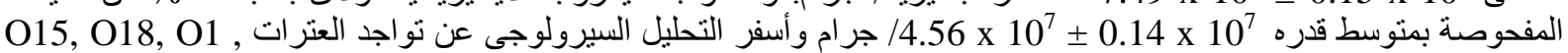

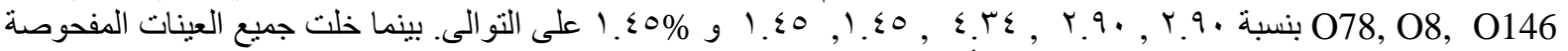
من ميكروب السالمونيلا. وقد خلصت الدر اسة الي أن الجبن الطرى منزوع الدسم يمثل خطر ا صحيا فى مناطق الدر اسة. الكلمات الدالة: الانتيروباكترياسى، الجبن الطرى منزوع الدسم و الايشيريشيا كو لاى. 